
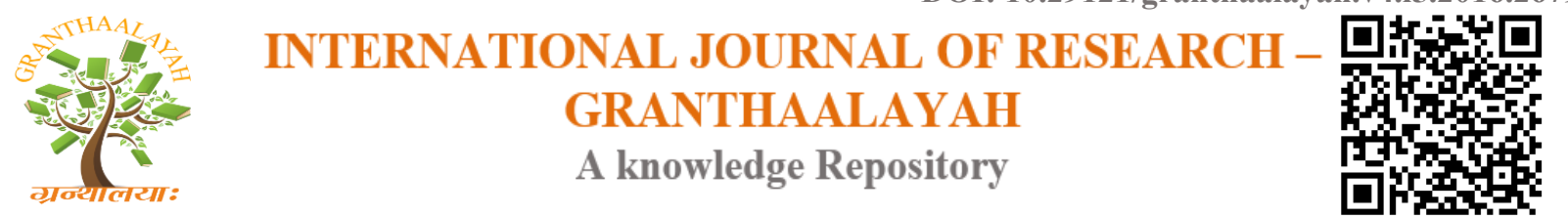

Management

\title{
A STUDY ON INITIATIVE BY MINISTRY OF TOURISM FOR PROMOTION OF WELLNESS AND MEDICAL AS NICHE TOURISM PRODUCT
}

\author{
Dr. Sanjeevani Kailas Rahane ${ }^{* 1}$, Mr. Roshen Raju ${ }^{2}$ \\ ${ }^{*}$ Research Guide, Savitribai Phule Pune University, INDIA \\ ${ }^{2}$ Research Scholar, Savitribai Phule Pune University, INDIA
}

\begin{abstract}
Worldwide Tourism is now recognized as an accelerator of growth. Tourism has great capacity to generate large scale employment and additional income source to the various skilled and unskilled. Several countries have transformed their economics by developing their tourism potential.

But in this current era there is a change in the concept of traditional tourism. The Wellness and Medical Tourism which is one of the numerous categories of tourism has gained high popularity. In the recent years, there has been a significant growth in this sector and is swiftly becoming a billion dollar industry. India is one of the favorable destination for wellness and medical tourism in the global scenario.

This research paper focuses on various initiatives undertaken by the Ministry of Tourism, Government of India for promotion of Wellness and Medical Tourism. Wellness and Medical Tourism forms a niche market as it is still a developing sector of tourism. The main of focus of Ministry of tourism is to promote this sector of tourism as a niche product. The initiatives taken will bring many direct and indirect benefits to the people.
\end{abstract}

Keywords:

Wellness and Medical tourism, Ministry of Tourism, Promotion.

Cite This Article: Dr. Sanjeevani Kailas Rahane, and Mr. Roshen Raju, "A STUDY ON INITIATIVE BY MINISTRY OF TOURISM FOR PROMOTION OF WELLNESS AND MEDICAL AS NICHE TOURISM PRODUCT" International Journal of Research Granthaalayah, Vol. 4, No. 5 (2016): 73-79.

\section{INTRODUCTION}

Tourism has evolved into a global business. A number of entities are involved in contributing to the success of this industry. With the growth rate of $4 \%$ per year, which has been estimated by the world tourism organization, the tourism industry is an instrument of change. It has contributed around $9 \%$ to the world Gross Domestic Product and about $8 \%$ for employment. 
The Indian tourism industry is also estimated to be growing at around $10.3 \%$. There is also a rise in the number of foreign tourist arriving in India .It is estimated to rise from around 1 billion in 2015 to 1.9 billion by 2028 .

Thus tourism is proving to be a major tool which is helping all the economies worldwide for generations of new employment opportunities to eradicate poverty.

Wellness and Medical Tourism is one of the new growing categories of the Tourism industry. It's rapidly growing into multibillion-dollar industry. It is an industry which is a culmination of 2 largest industries viz. Medicine and Tourism.

\section{WELLNESS AND MEDICAL TOURISM}

Wellness and Medical tourism explained by Goodrich. G \& Goodrich J (1987), is an activity wherein the Tourist destination try to deliberately promote its healthcare services and facilities. This is done in addition with providing all the regular tourist amenities thus attracting tourists from all around the world.

It also involves on improving Wellness and Medical tourism is an integration of medical pathology and surgery as well as wellness services, which focuses on betterment of health and state of wellbeing of the tourist,

Bookman, M. \& Bookman, K. (2007) in their research paper titled "Medical Tourism in Developing Countries " have signified that the medical tourism is a form of travel wherein the aim of tourist is improving one's health issues by utilizing the various wellness and medical facilities provided by the tourist facilities .

Laws (1996) has defined it as a travel from home to other destination to improve one's health condition as one type of leisure which includes getting indigenous and substitute medical services undertaken with the focus on addressing a health concern.

In this kind of Tourism the customer is the patient who travel oversees to foreign countries to obtain heath care services from them which are provided at affordable prices. Most of the tourist try avail the better quality treatment from these countries as the same kind of facilities are unavailable at their home place or is at very high cost.

After Information Technology, Wellness and Medical Tourism is poised to be the next Indian success story.

\section{MINISTRY OF TOURISM}

The Ministry of Tourism is the nodal agency for the formulation of national policies and programmes. It co-ordinates activities of various Central Government Agencies, State Governments or UTs and the Private Sector for the development and promotion of tourism in the country. The Ministry of Tourism functions as the central agency for the development of tourism in the country. It plays a crucial role in coordinating and supplementing the efforts of the State or 
Union Territory Governments, catalyzing private investment, strengthening promotional and marketing efforts and in providing trained manpower resources.

\section{RESEARCH METHODOLOGY}

Research Design- Exploratory Research Design

Data Collection -Secondary Data collected from various sources including Journal, research paper, Internet and websites is used for the purpose of study.

\section{INITIATIVE STEPS TAKEN BY THE MINISTRY OF TOURISM, GOVERNMENT OF INDIA}

\section{A. Association:}

The ministry of tourism has proposed to all stakeholders who are engaged in Wellness and Medical Tourism activities to form either Wellness and Medical Tourism Association of India or Wellness Tourism Association of India or Medical Tourism Association of India.This association will have an all India open membership. It will be registered as a non-profitable society and will conduct elections at regular intervals along with holding Audit of Accounts once a year.

\section{B. Provision under the MDA scheme:}

The ministry of tourism will provide the financial assistance for Wellness Tourism Service Providers and Medical Tourism Service Providers as per the provisions of the Marketing Development Assistance (MDA) scheme. The provision scheme which is administered by the Ministry of Tourism, will be provided to

a) The Wellness Tourism Service Providers which include Travel Agents and Tour Operators engaged in Wellness Tourism, SPAs and Wellness Centers.

b) Medical Tourism Service Providers which include Travel Agents and Tour Operators engaged in Medical Tourism and Hospital

c) Representatives of Wellness Centres including SPAs accredited by the National Accreditation Board of Hospitals and or AYUSH or State or UT Governments

d) Representatives of Hospitals accredited by the Joint Commission for International Accredited Hospitals and or the National Accreditation Board of Hospitals , for the fairs or events or road shows approved by the Ministry of Tourism

\section{Constitution of WMTPC:}

The Wellness and Medical Tourism Promotion Committee (WMTPC) will be constituted. This committee will consider all financial assistance except Marketing Development Assistance. The tenure of this Committee will be for 2 years from the date of its constitution.

The Hon'ble Minister of Tourism will be the chairman of the WMPTC and will consists of the following members

i. Secretary (Ministry of Tourism),

ii. Additional Secretary(Ministry of Tourism),

iii. Additional Secretary \& Financial Adviser (Ministry of Tourism)

iv. Joint Secretary(Ministry of Tourism)

v. Joint Secretary( Ministry of Culture) 
vi. Joint Secretary (Department of AYUSH)

vii. Joint Secretary (Ministry of Health and Family Welfare)

viii. Member Secretary: Secretary General(Indian Medical Association)

ix. Representative of Association of Domestic Tours Operators of India

x. Representative of Medical and Wellness Associations

xi. Representative of Hotel Association of India

xii. 2 members of National Accreditation Board for Hospitals and Healthcare Services

xiii. Representative of Federation of Hotels and Restaurants Association of India

xiv. National President and 2 Representatives of Indian Medical Associations

xv. Representative of Delhi Medical Council

xvi. 2 Representatives of Wellness and Medical Tourism stakeholders who will be nominated by Ministry of Tourism

xvii. Representative of Indian Association of Tour Operators

xviii. Representative of Federation of Indian Chambers of Commerce and Industry

xix. 3 Representatives from Medical Industry on behalf of stakeholders

xx. Representative of Indian Chamber of Commerce

\section{Human resource Training:}

Well trained and qualified human resource is a vital element of any tourism product. There is a need to provide trainings at the basic, higher and advanced level so that a better service standard is maintained and consumer satisfaction is achieved. Keep this need in mind the Ministry of Tourism will provide financial support for training courses which will be focused on skill upgradation, skill certification courses and skill providing for all the people engaged in Wellness and Medical Tourism sector.

This will be in accordance to the Capacity Building for Service Providers (CBSP) scheme guidelines of the Ministry of Tourism.

\section{E. Publicity: Marketing and Promotional measures}

Wellness \& Medical Tourism market can be reached through a number of marketing and promotional measures. Bu the cost incurred for each of these promotional activities is in huge amount. So keeping this in mind the Ministry of Tourism is considering to provide financial support in the ratio of 50:50 for making publicity and promotional material.

But this financial support will be subjected to the condition that the Ministry of Tourism and they will provide a maximum of Rs.10.00 lakh under the category for each stakeholder in a financial year. This support will not be provided for airing time on radio or television.

\section{a) Promotion through workshops / events / meets / seminars:}

For the purpose of organizing workshops/events/meets/seminars which focus on promotion of Wellness and Medical Tourism financial assistance will be provided by the Ministry of Tourism. But it will be subject to the following conditions;

i. A maximum amount of Rs.10.00 lakh will be provided on 50:50 cost sharing basis.

ii. A minimum of 100 participants out of which at least 50 percent should be foreigners. 


\section{b) For organizing Wellness and Medical Tourism Promotion Shows:}

The promotion shows with participation of suppliers, buyers and exhibits will be given financial assistance by the Ministry of Tourism subject to the condition that

i. The maximum financial assistance will be up to a maximum of Rs.25.00 lakh on 50:50 sharing basis.

ii. A minimum of 75 participants will participate in the show and there will be at least 40 percent foreign buyers.

\section{c) Participation in fairs and events:}

For the promotion of Wellness and Medical Tourism, the Ministry of Tourism will provide space up to 4 square meters to the Associations at major international fairs and events.

\section{d) Use of Incredible India logo:}

The Ministry of Tourism will give authorization for the use of Incredible India logo for the wellness and medical tourism promotion events, literature, films etc., as per the approved procedure from time to time. This will help to promote the wellness and medical tourism around the globe.

\section{CONCLUSION}

Tourism is recognized as an engine of growth in the various economics in the world. Tourism has great ability to generate large scale employment and provide as an additional income source to the skilled and unskilled people. A number of countries worldwide have transformed their economies by developing their tourism potential.

Through this research paper we are able to understand the various initiatives taken by the Ministry of Tourism, Government of India for promotion of Wellness and Medical Tourism viz. Association, Constitution of Wellness and Medical Tourism Promotion Committee (WMTPC), Provision under the Marketing Development Assistance (MDA) scheme ,Human resource Training, Marketing and Promotional measures.

India is a reasonable destination for people in need of best medical care at cost much lower than that of developed countries. These initiatives will definitely help for the promotion of Wellness and Medical Tourism as niche tourism product and also act as a major boon for the various people involved in Wellness and Medical Tourism.

\section{REFERENCES}

[1] www.tourism.gov.in

[2] www.iato.in

[3] www.fhrai.com

[4] www.ima-india.org

[5] Ramesh U. and Joseph Kurian (2011), "A Study to develop an advanced marketing strategy for wellness tourism in Kerala based on the prevailing scenario", International Journal of Multidisciplinary Research 
[6] Dawn, Suman Kumar and Swati Pal (2011)," Medical Tourism in India: Issues, Opportunities and Designing Strategies for Growth and Development", International Journal of Multidisciplinary Research

[7] Shaik Shahazadi Begum (2012), "Medical and Wellness Tourism: Opportunities and Challenges-Marketing 'Brand India,,"

[8] Bookman, M. \& Bookman, K. (2007), "Medical Tourism in Developing Countries “, New York : Palgrave Macmillan

[9] Laws, E.(1996) : "Health tourism : A business opportunity approach. In S. Clift and S.J. page (Eds.) Health and the International Tourist, Routledge : London and New York.

[10] Goodrich , G.\& GoodrichJ. (1987): "Healthcare Tourism-An exploration study", Tourism Management. 